\title{
Sagittal Otolith Morphology of Sharpsnout Seabream Diplodus puntazzo (Walbaum, 1792) in the Aegean Sea
}

\author{
Morfología de los Otolitos Sagitales del Sargo Picudo \\ Diplodus puntazzo (Walbaum, 1792) en el Mar Egeo
}

Derya Bostanci"; Mahmut Yilmaz ${ }^{* *}$; Serdar Yedier*; Gülsah Kurucu*; Seda Kontas*; Muammer Darçin* \& Nazmi Polat ${ }^{* * * *}$

BOSTANCI, D.; YILMAZ, M.; YEDIER, S.; KURUCU, G.; KONTAS, S.; DARÇIN, M. \& POLAT, N. Sagittal otolith morphology of sharpsnout seabream Diplodus puntazzo (Walbaum, 1792) in the Aegean sea. Int. J. Morphol., 34(2):484-488, 2016.

SUMMARY: The morphology, biometry and shape indices of the left and right sagittal otoliths were studied for sharpsnout seabream, Diplodus puntazzo species from Aegean Sea. The shape, sulcus acusticus shape, proximal and distal surfaces, anterior and posterior regions of left and right sagittal otoliths for a total of $52 \mathrm{D}$. puntazzo were analyzed. The morphometric measurements such as weight, length, width, area and perimeter were recorded for each pair of sagittal otoliths of the sharpsnout seabream. The shape indices such as form factor, roundness, aspect ratio, circularity, rectangularity, and ellipticity were calculated for left and right sagittal otoliths of D. puntazzo. The otolith width and ellipticity were significantly different $(\mathrm{P}<0.05)$ for left and right sagittal otolith measurements and shape indices, respectively in D. puntazzo inhabiting the Aegean Sea. Morphological characteristics of fish otoliths were highly variable in species and populations; there was limited information on the sagittal otolith morphology and shape indices. The present study provided sufficient information of the sharpsnout seabream left and right otolith morphologies, biometry, and shape indices in the Aegean Sea, they may provide a useful tool for marine and freshwater species discrimination and identification in further investigations.

KEY WORDS: Morphology; Biometry; Shape indices; Diplodus puntazzo.

\section{INTRODUCTION}

The term otolith refers to calcareous structures in the inner ear of teleost fish. They are three pairs such as sagittae, lapilli, and asterisci. Their shapes and morphologies are species specific (Lombarte \& Castellón, 1991). Due to the combined effects of genetics and environment, fish with different life histories often show variation in otolith morphology and shape. Therefore, the characteristics have been considered crucial criteria in fisheries (Bostanci et al., 2015). Their species specific properties have been extensively used to identification, discrimination, and ageing (Cardinale et al., 2004) in freshwater and marine species. Studies of otolith morphology, contour shape have recently increased more and more in importance with the development of digital techniques, image analysis systems and shape analysis methods (Zhuang et al., 2014; Bostanci et al.). The otoliths and the techniques-methods have proven to be a powerful time- and cost-efficient in the identification of various freshwater and marine species (Sadighzadeh $e t$ al., 2012; Tuset et al., 2013; Bostanci et al.).
Sharpsnout seabream, Diplodus puntazzo (Walbaum, 1792) is a demersal marine, brackish, benthopelagic, and oceanodromous fish species in Sparidae (Riede, 2004). The sharpsnout seabream was found in groups over rocky and sandy bottoms and down to depths of about $150 \mathrm{~m}$. This species is widespread in the Aegean Sea, the Mediterranean and the Black Sea. D. puntazzo is commercial important fish species in all the coastal areas of Turkey, especially in the Aegean Sea for fisheries and fishery management (Altin $e t$ al., 2015).

The otoliths are used in various studies such as age determination, fish growth and population dynamics all over the world (Bostanci et al.); however, the otolith morphology and shape indices for $D$. puntazzo with other variables remains largely unknown or is limited in Turkey. The aims of the current paper were to describe the morphology and shape indices of left and right sagittal otoliths of the $D$. puntazzo in the Aegean Sea.

\footnotetext{
* Department of Biology, Ordu University, Ordu, Turkey.

** Department of Biology, Ahi Evran University, Kırsehir, Turkey.

**** Department of Biology, 19 Mayis University, Samsun, Turkey.
} 


\section{MATERIAL AND METHOD}

Diplodus puntazzo specimens were sampled in the Aegean Sea (Fig. 1). Each D. puntazzo was cleaned from external materials and weighted to the nearest $0.01 \mathrm{~g}$. Their standard length (SL), fork length (FL) and total length (TL) were measured to the nearest $0.1 \mathrm{~cm}$ by digital caliper.

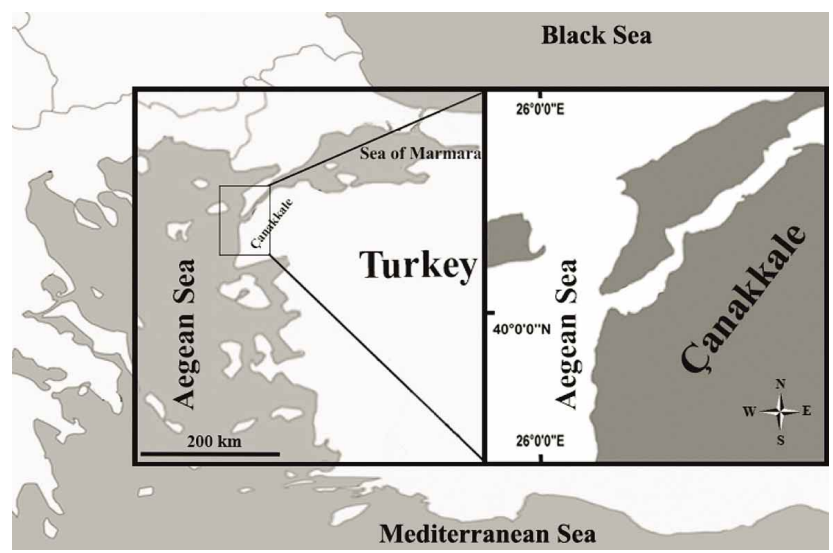

Fig. 1. Sampling area of Diplodus puntazzo in the Aegean Sea.

The sharpsnout seabream sagittal otolith pairs were removed and cleaned. The otolith pairs were weighed to the nearest $0.0001 \mathrm{~g}$. Each otolith pairs were photographed on distal and proximal surface by using Leica S8APO microscope and computer-connected camera system. The otolith length $(\mathrm{OL}, \mathrm{mm})$, otolith width $(\mathrm{OW}, \mathrm{mm})$, otolith area $\left(\mathrm{A}, \mathrm{mm}^{2}\right)$ and otolith perimeter $(\mathrm{P}, \mathrm{mm})$ were measured using the photographs by Leica Application Suite software. While sagittal otolith length was measured from anterior to posterior axis, the otolith width was from dorsal to ventral edge through the otolith focus.

The paired t-test was applied in order to determine the differences between right and left otoliths. All calculations were performed with MINITAB 17.0 statistical analysis software program. $D$. puntazzo sagittal otolith shape indices were calculated using the following formulas (Tuset et al., 2003; Ponton, 2006):

. Form factor: $4 \pi$ x Otolith Area x Otolith Perimeter ${ }^{-2}$

- Roundness: 4 x Otolith Area x $\left(\pi \text { x Otolith Length }{ }^{2}\right)^{-1}$

- Aspect ratio: Otolith Length $x$ Otolith Width ${ }^{-1}$

- Circularity: Otolith Perimeter ${ }^{2}$ x Otolith Area $^{-1}$

- Rectangularity: Otolith Area x (Otolith Length x Otolith Width $)^{-1}$

- Ellipticity: (Otolith Length - Otolith Width) x (Otolith Length + Otolith Width) ${ }^{-1}$
The values of form factor (FF), roundness (RD), aspect ratio (AR), circularity $(\mathrm{C})$, rectangularity $(\mathrm{R})$ and ellipticity (E) were calculated for D. puntazzo left and right sagittal otoliths in the Aegean Sea. Sagittal otolith morphological characters such as otolith shape, sulcus acusticus shape, proximal and distal surfaces, anterior region, and posterior region were investigated for the left and right sagittal otolith of the sharpsnout seabream in the Aegean Sea.

\section{RESULTS}

A total of $52 \mathrm{D}$. puntazzo were examined and their standard length, fork length, total length and weight distributions were determinate such as $11.2-24.5 \mathrm{~cm}, 12.6-$ $26.8 \mathrm{~cm}, 14.2-29.0 \mathrm{~cm}$, and $54.3-454.4 \mathrm{~g}$ respectively in the Aegean Sea. Left and right sagittal otolith distal (a) and proximal (b) surfaces photographs were presented with otolith length, otolith width, and otolith area for the sharpsnout seabream in the Aegean Sea (Fig. 2). All sagittal otolith measurements were determinate for each sharpsnout seabream and the summary of descriptive statistics such as mean, standard deviation (SD), standard error (SE), minimum, and maximum for left and right sagittal otoliths and paired-t test results were shown in Table I.

While the left otolith length and otolith perimeter were bigger than the right otolith values, the other right otolith measurements such as otolith weight, otolith width, and otolith area were bigger than left otolith of the sharpsnout seabream in the Aegean Sea (Tab. I). According to paired ttest results, the width of left and right otolith were estimated as $3.561 \mathrm{~mm}$ and $3.608 \mathrm{~mm}$, respectively and the differences between left and right otolith width values were statistically important $(\mathrm{P}<0.05)$; however, other measurements values were not significant $(\mathrm{P}>0.05)$ for between left and right otolith values of the species (Tab. I).

The otolith shape indices such as form factor (FF), roundness (RD), aspect ratio (AR), circularity (C), rectangularity (R) and ellipticity (E) were calculated using the left and right otolith sagittal measurements values for the sharpsnout seabream in the Aegean Sea (Tab. II). The mean values of FF, RD, AR, E, C, and R were calculated as $0.72061,0.53226,1.7325,0.26735,17.507$, and 0.72199 , respectively for $D$. puntazzo left sagittal otolith and 0.72912 , $0.53825,1.7092,0.26074,17.295$, and 0.71954 , respectively right sagittal otolith of the shape indices in the Aegean Sea (Table II). The difference between right and left otoliths shape indices were not important statistically $(\mathrm{P}>0.05)$, except ellipticity of the species in the Aegean Sea (Table II). 


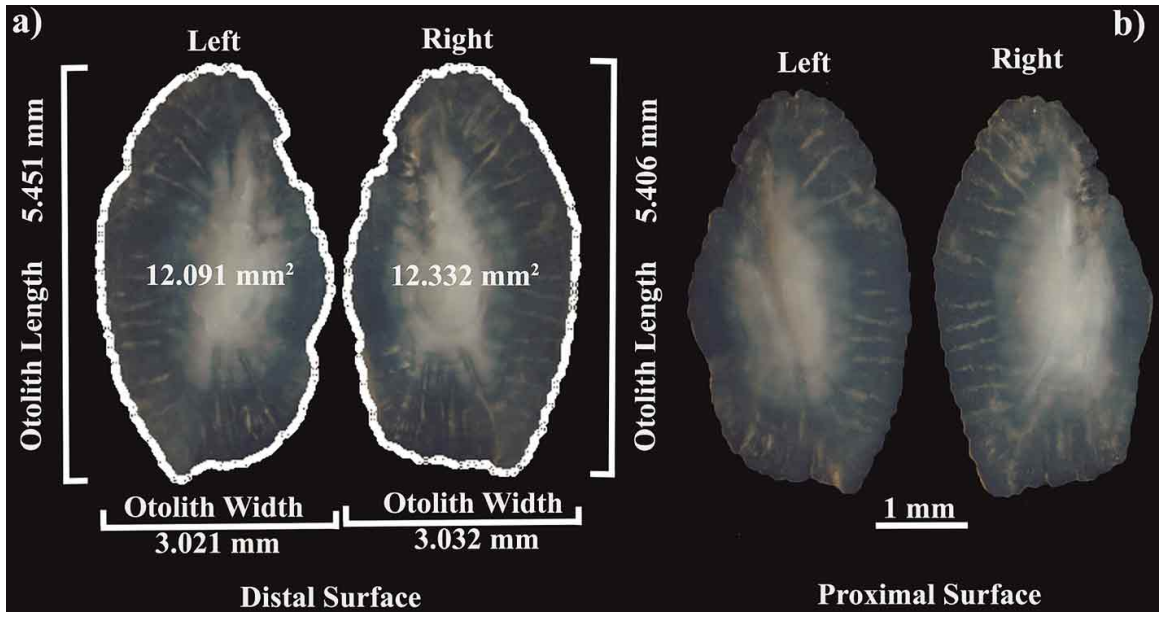

Fig. 2. Left and right sagittal otolith distal (a) and proximal (b) surfaces from Diplodus puntazzo in the Aegean Sea.

Table I. Summary of descriptive statistics and paired t-test results for left and right sagittal otoliths measurements of Diplodus puntazzo in the Aegean Sea.

\begin{tabular}{llccccccc}
\hline Otolith Measurements & & Mean & SE & SD & Min & Max & Sig. \\
\hline \multirow{2}{*}{ Otolith Weight } & Left & 0.02173 & 0.00105 & 0.00688 & 0.0112 & 0.0389 & $\mathrm{P}>0.05$ & 0.377 \\
& Right & 0.02201 & 0.00093 & 0.00661 & 0.0117 & 0.0406 & & \\
Otolith Length & Left & 6.171 & 0.105 & 0.691 & 5.169 & 7.965 & $\mathrm{P}>0.05$ & 0.935 \\
& Right & 6.164 & 0.091 & 0.642 & 5.116 & 7.602 & & \\
Otolith Width & Left & 3.561 & 0.053 & 0.345 & 3.021 & 4.406 & $\mathbf{P}<\mathbf{0 . 0 5}$ & $\mathbf{0 . 0 0 6}$ \\
\multirow{3}{*}{ Otolith Area } & Right & 3.608 & 0.045 & 0.321 & 2.960 & 4.549 & & \\
\multirow{3}{*}{ Otolith Perimeter } & Left & 16.010 & 0.508 & 3.331 & 11.389 & 25.671 & $\mathrm{P}>0.05$ & 0.148 \\
& Right & 16.101 & 0.413 & 2.923 & 11.766 & 24.200 & & \\
& Left & 16.671 & 0.305 & 2.001 & 14.199 & 22.017 & $\mathrm{P}>0.05$ & 0.913 \\
\hline
\end{tabular}

Abbreviations: $\mathrm{SE}=$ Standard error; $\mathrm{SD}=$ Standard deviation; Min=Minimum; Max=Maximum; Sig=Significant differences.

Table II. Summary of descriptive statistics of shape indices for left and right sagittal otoliths of Diplodus puntazzo in the Aegean Sea.

\begin{tabular}{llccccccc}
\hline \multicolumn{2}{l}{ Otolith Shape indic } & Mean & SE & SD & Min & Max & Sig. \\
\hline \multirow{2}{*}{ Form factor } & Left & 0.72061 & 0.00727 & 0.04767 & 0.62247 & 0.79891 & $\mathrm{P}>0.05$ & 0.249 \\
& Right & 0.72912 & 0.00631 & 0.04462 & 0.61863 & 0.80157 & & \\
\multirow{2}{*}{ Roundness } & Left & 0.53226 & 0.00467 & 0.03064 & 0.46837 & 0.59197 & $\mathrm{P}>0.05$ & 0.196 \\
& Right & 0.53825 & 0.00502 & 0.03549 & 0.44049 & 0.62333 & & \\
\multirow{2}{*}{ Aspect ratio } & Left & 1.7325 & 0.0134 & 0.0880 & 1.6092 & 1.9853 & $\mathrm{P}>0.05$ & 0.057 \\
& Right & 1.7092 & 0.0148 & 0.1049 & 1.4999 & 2.0299 & & \\
\multirow{2}{*}{ Ellipticity } & Left & 0.26735 & 0.00353 & 0.02318 & 0.23349 & 0.33005 & $\mathbf{P}<\mathbf{0 . 0 5}$ & $\mathbf{0 . 0 3 5}$ \\
& Rircularity & 0.26074 & 0.00393 & 0.02780 & 0.19995 & 0.33991 & & \\
\multirow{2}{*}{ Rectangularity } & Left & 17.507 & 0.183 & 1.200 & 15.722 & 20.178 & $\mathrm{P}>0.05$ & 0.328 \\
& Right & 17.295 & 0.161 & 1.142 & 15.669 & 20.303 & & \\
\hline
\end{tabular}

Abbreviations: $\mathrm{SE}=$ Standard error; $\mathrm{SD}=\mathrm{Standard}$ deviation; Min=Minimum; Max=Maximum; Sig=Significant differences .

Some important otolith morphology features such as otolith and sulcus acusticus shapes, proximal and distal surfaces, anterior and posterior regions were determinate for left and right sagittal otoliths of the sharpsnout seabream and their general morphology were shown (Table III). 
Table III. Left and right sagittal otolith morphology features of Diplodus puntazzo in the Aegean Sea.

\begin{tabular}{llccccc}
\hline $\begin{array}{c}\text { Otolith Morphology Features } \\
\text { Diplodus } \\
\text { puntazzo }\end{array}$ & $\begin{array}{l}\text { Otolith } \\
\text { Shape }\end{array}$ & $\begin{array}{c}\text { Sulcus acusticus } \\
\text { Shape }\end{array}$ & $\begin{array}{c}\text { Proximal } \\
\text { Surface }\end{array}$ & $\begin{array}{c}\text { Distal } \\
\text { Surface }\end{array}$ & $\begin{array}{c}\text { Anterior } \\
\text { Region }\end{array}$ & $\begin{array}{c}\text { Posterior } \\
\text { Region }\end{array}$ \\
\hline $\begin{array}{l}\text { Left Otolith } \\
\text { Right Otolith }\end{array}$ & $\begin{array}{l}\text { Pentagonal } \\
\text { Pentagonal } \\
\text { Distal Surface }\end{array}$ & $\begin{array}{c}\text { Heterosulcoid } \\
\text { Heterosulcoid }\end{array}$ & $\begin{array}{c}\text { Concave } \\
\text { Concave }\end{array}$ & $\begin{array}{c}\text { Convex } \\
\text { Convex } \\
\text { Proximal Surface }\end{array}$ & $\begin{array}{c}\text { Round } \\
\text { Round }\end{array}$ & $\begin{array}{c}\text { Oblique } \\
\text { Oblique }\end{array}$ \\
\end{tabular}

\section{DISCUSSION}

The current study is the first to compare left and right sagittal otolith biometry, shape indices and morphology of D. puntazzo in the Aegean Sea. Otolith morphology was indicated species and genus diagnostic in marine and freshwater species (Bostanci et al.; Tuset et al., 2015). Small differences in left and right sagittal otolith shape and shape indices were determine in D. puntazzo inhabiting the Aegean Sea (Tables II and III). Moreover, the left and right otolith sides are denticulated for the sharpsnout seabream in the Aegean Sea (Table III). Lombarte \& Cruz (2007) indicated that individuals of the same species with their phylogenetic patterns can be reflected in their otolith morphology and patterns as it's seen in the current study.

All studied sagittal otolith (left-right) irregular pentagonal shapes were characterized by the sharpsnout seabream inhabiting the Aegean Sea (Table III). However, the sharpsnout seabream sagittal otolith shapes were determinate as elliptic in western Mediterranean, north and central eastern Atlantic (Tuset et al., 2008). According to the present study, min-max circularity and rectangularity were calculated as 15.6-20.3,0.6-0.7, respectively of $D$. puntazzo in the Aegean Sea; however, they were calculated as 15.6-16.7, 0.2-0.3, respectively of D. puntazzo in western Mediterranean, north and central eastern Atlantic by Tuset et al. (2008). Environmental and ecological factors especially habitat type inducing differences in food quality and quantity affect otolith morphology (Vignon et al., 2008); therefore these types of differences in $D$. puntazzo may be a primary factor in the development of differences in otolith morphometry in the different habitats such as Aegean Sea and western Mediterranean, north and central eastern Atlantic.

In that study, left and right otolith pairs were not compared for D. puntazzo. In the current study, left and right otolith pairs were compared and their sulcus acusticus shape is determinate heterosulcoid and their sulcus acusticus is deep and well-defined for sagittal otolith of sharpsnout seabream in the Aegean Sea (Table III). The left and right otolith were concave in the proximal surface and convex in the distal surface for D. puntazzo (Table III). While anterior region is round for left and right sagittal otolith in the sharpsnout seabream, posterior region is oblique for left and right sagittal otolith in the same species in the Aegean Sea (Table III).

It is the first time, the difference of otolith shape indices were investigated left and right pairs of the shape indices a member of Sparidae in the Aegean Sea. The ellipticity was statistically important between right and left otoliths of the sharpsnout seabream in the Aegean Sea (P $<0.05)$. The morphologic diversity of the sagittal otoliths are still very poorly known and limited information, the using D. puntazzo left and right otolith morphologies may be a useful tools for marine and freshwater species identification, taxonomic, and phylogenetic information in further investigations. However, for powerful identification and determination, the further investigation is needed, including a comparative study with otolith morphometry, biometry, shape indices, and genetic methods in male-female individuals and their left-right otolith pairs of various marine and freshwater fish species.

BOSTANCI, D.; YILMAZ, M.; YEDI 'ER, S.; KURUCU, G.; KONTAS, S.; DARÇIN, M. \& POLAT, N. Morfología de los otolitos sagitales del sargo picudo Diplodus puntazzo (Walbaum, 1792) en el Mar Egeo. Int. J. Morphol., 34(2):484-488, 2016.

RESUMEN: Los índices morfológicos, biometría y la forma de los otolitos sagitales izquierdo y derecho se estudiaron para la especie sargo picudo, Diplodus puntazzo del mar Egeo. Se analizaron en 52 D. puntazzo la forma del surco acústico, las superfi- 
cies proximal y distal y las regiones posteriores de los otolitos sagitales izquierdo y derecho. Además, se registraron para cada par de otolitos sagitales las mediciones morfométricas de peso, longitud, ancho y perímetro. Se calcularon en ambos otolitos sagitales los índices de forma, factor de forma, relación de aspecto, circularidad, ortogonalidad y elipticidad. En el D. puntazzo que habita en el mar Egeo, el ancho y elipticidad de los otolitos fueron significativamente diferentes $(\mathrm{P}<0,05)$, para las mediciones de otolitos sagitales izquierdo y derecho, respectivamente. Existen gran variabilidad en las características morfológicas de los otolitos de diferentes especies y poblaciones de peces, asimismo es limitada la información de los índices morfológicos y la forma de los otolitos sagitales. El presente estudio proporciono información suficiente sobre la morfología y biometría de los otolitos izquierdo y derecho del sargo picudo en el Mar Egeo, lo que puede proporcionar una herramienta útil para la discriminación e identificación de especies marinas de agua dulce y para nuevas investigaciones.

PALABRAS CLAVE: Morfología; Índices de biometría; Índices de forma; Diplodus puntazzo.

\section{REFERENCES}

Altin, A.; Özen, Ö.; Ayyildiz, H. \& Ayaz, A. Feeding habits and diet overlap of juveniles of 2 sparids, Diplodus puntazzo (Walbaum, 1792) and Diplodus vulgaris (Geoffroy SaintHilaire, 1817), from the North Aegean Sea of Turkey. Turk. $J$. Zool., 39(1):80-7, 2015.

Bostanci, D.; Polat, N.; Kurucu, G.; Yedier, S.; Kontas, S. \& Darçin, M. Using otolith shape and morphometry to identify four Alburnus species (A. chalcoides, A. escherichii, A. mossulensis and A. tarichi) in Turkish inland waters. J. Appl. Ichthyol., 31(6):1013-22, 2015.

Cardinale, M.; Doering-Arjes, P.; Kastowsky, M. \& Mosegaard, H. Effects of sex, stock and environment on the shape of known-age Atlantic cod (Gadus morhua) otoliths. Can. J. Fish Aquat. Sci., 61(2):158-67, 2004.

Lombarte, A. \& Castellón, A. Interspecific and intraspecific otolith variability in the genus Merluccius as determined by image analysis. Can. J. Zool., 69(9):2442-9, 1991.

Lombarte, A. \& Cruz, A. Otolith size trends in marine fish communities from different depth strata. J. Fish Biol., 71(1):5376, 2007.

Ponton, D. Is geometric morphometrics efficient for comparing otolith shape of different fish species? J. Morphol., 267(6):7507, 2006

Riede, K. Global Register of Migratory Species - From Global to Regional Scales. Final Report of the R\&D-Projekt 80805081. Bonn, Federal Agency for Nature Conservation, 2004.
Sadighzadeh, Z.; Tuset, V. M.; Valinassab, T.; Dadpour M. R. \& Lombarte, A. Comparison of different otolith shape descriptors and morphometrics for the identification of closely related species of Lutjanus spp. from the Persian Gulf. Mar. Biol. Res., 8(9):802-14, 2012.

Tuset, V. M.; Lozano, I. J.; González, J. A.; Pertusa, J. F. \& GarcíaDíaz, M. M. Shape indices to identify regional differences in otolith morphology of comber, Serranus cabrilla (L., 1758). J. Appl. Ichthyol., 19(2):88-93, 2003.

Tuset, V. M.; Lombarte, A. \& Assis, C. A. Otolith atlas for the western Mediterranean, north and central eastern Atlantic. Sci. Mar., 72(S1):7-198, 2008.

Tuset, V. M.; Parisi-Baradad, V. \& Lombarte, A. Application of otolith mass and shape for discriminating scabbardfishes Aphanopus spp. in the north-eastern Atlantic Ocean. J. Fish Biol., 82(5):1746-52, 2013.

Tuset, V. M.; Imondi, R.; Aguado, G.; Otero-Ferrer, J. L.; Santschi, L.; Lombarte, A. \& Love, M. Otolith patterns of rockfishes from the northeastern Pacific. J. Morphol., 276(4):458-69, 2015.

Vignon, M.; Morat, F.; Galzin, R. \& Sasal, P. Evidence for spatial limitation of the bluestripe snapper Lutjanus kasmira in French Polynesia from parasite and otolith shape analysis. J. Fish Biol., 73(10):2305-20, 2008.

Zhuang, L.; Ye, Z. \& Zhang, C. Application of otolith shape analysis to species separation in Sebastes spp. from the Bohai Sea and the Yellow Sea, northwest Pacific. Environ. Biol. Fish., 98(2):547-58, 2015.

\section{Correspondence to: \\ Derya Bostancı \\ Department of Biology \\ Ordu University \\ Ordu \\ TURKEY}

Email:deryabostanci@gmail.com

Received: 21-10-2015

Accepted: 26-02-2016 